\title{
Training Model and Quality of College Students in English Major
}

\author{
https://doi.org/10.3991/ijet.v16i04.20479 \\ Jingwei Tang \\ Chongqing Technology and Business University, Chongqing, China \\ Assumption University, Bangkok, Thailand \\ fionachen2020@163. com
}

\begin{abstract}
This paper mainly analyzes the training model and quality of college students in English major, aiming to improve the training of English majors in colleges. Firstly, the current problems in the training of college students in English major were summarized, the influencing factors of the training quality were identified, and the implementation strategies and paths for the training model were introduced in details. On this basis, the author designed an evaluation index system, set up an evaluation model for the training quality of college students in English major, and explained the fuzzy decision process in the evaluation. The proposed evaluation model effectively quantifies the training quality of English majors in colleges. The research results provide an important guidance for pinpointing the weak links in the training model of English majors in colleges, and laying a solid basis for improving the training quality.
\end{abstract}

Keywords - College student training model, English major, quality analysis, fuzzy decision

\section{Introduction}

In the context of economic globalization, contemporary society has an increasingly urgent demand for high-level English professionals, thus pushing English education to a more important position in higher education [1-4]. As a result, how to improve the quality of college students in English major has become an important research topic in the field of higher education, and how to form a scientific and reasonable training model has become a research hotspot as well [5-8]. Gao et al. discussed the realization of the full integration of information technology and college English teaching, and analyzed a hybrid college English teaching model based on the Rain Classroom [9]. $\mathrm{Li}$ and $\mathrm{Li}$ discussed a college English teaching model from a cross-cultural perspective, which has a positive role in cultivating college English majors' ability in crosscultural learning and communication [10]. Zhou discussed a PBL-based college English teaching model aiming at cultivating application-type talents, which can act as a reference for improving college students' comprehensive ability [11]. He analyzed the problems facing college English teaching in the new era and proposed a few countermeasures, which provides a reference for the training of college English majors [12]. Dvorghets and Shaturnaya discussed how to cultivate students' media literacy in Eng- 
lish teaching, which has a promotive effect on improving the quality of student training [13]. DeWaelsche analyzed the feasibility of high-level questioning in studentcentered activities, which has a positive effect on improving the critical thinking of college English majors and increasing student participation [14].

The formulation and implementation of the training model of college English majors is a complex and systematic project, which involves the overall planning of multiple aspects such as teaching management, student management, student employment management, human resource management, material resource management, and financial resource management, etc. Under thus training model, how to effectively analyze the quality of college English majors is of great significance. Although existing evaluation methods do have certain practical values [15-17], their computation processes are often too complicated, so they have certain limitations in fuzzy information processing when dealing with system engineering problems. To this end, based on the existing research results, this paper further analyzes the training model of college English majors, and constructs an improved training quality system and mod$\mathrm{el}$, in the hopes of providing support for improving the training quality of college students in English major.

The research content of this paper consists of 5 parts. The first part summarizes existing research results concerning the training model of college English majors and quality analysis; the second part analyzes the current situation of the training of college English majors; the third part discusses the implementation strategies and paths of the training model, and gives specific implementation content; the fourth part establishes an improved training quality analysis model; the fifth part is the conclusion.

\section{Current Situations of the Training of College English Majors}

\subsection{Over emphasizing on examinations while ignoring quality education}

At present, the training of college English majors generally pays more attention to exam results, such as scores of college English courses or public English tests, and such score-centered education model is still the mainstream in colleges and universities. In terms of the teaching content of English education, it includes various forms such as English listening, oral English, English reading, English writing, and translation, etc., the teaching content is diversified and has obvious social characteristics. The goal of modern education is to cultivate professional talents with both high-level professional qualities and comprehensive qualities, therefore, exam scores should not be our only focus. 2.2 Unsystematic curriculum planning and there're weak links in comprehensive ability training

\subsection{Unsystematic curriculum planning and there're weak links in comprehensive ability training}

The training of the comprehensive ability of college English majors requires the assistance of a sound curriculum system. A set of systematic English curriculum system is both an important guarantee for the training of college English majors, and an important measure of the teaching ability of the English faculty in colleges and uni- 
versities. However, it can be seen from the implementation process that there're still shortcomings with the current curriculum planning of English major in colleges and universities, for example, the key content is not prominent and comprehensive, some focuses on the training of oral English, some pays more attention to reading, some may have attached equal importance to all aspects (listening/speaking/reading/writing) but fail to notice the correlations among these aspects or the analysis of the integration of these aspects is not deep enough. In addition, the content system and framework of the English curriculums can hardly adapt to the development requirements of the times. In some schools, the teaching materials are seriously outdated, or haven't been updated for even more than ten years, the construction of excellent English courses cannot meet the development requirements of higher education, resulting in a disconnection between student ability and social requirements. Especially with the deepening of discipline subdivision of modern higher education, English teaching for specific engineering disciplines has become more and more important, playing an increasingly significant role in cultivating English talents of different professions. However, there are obvious shortcomings in the current teaching system and curriculum planning system of English major in colleges and universities, which should be further improved in the future.

\subsection{Insufficient social practice, and the integration of theory and practice needs to be strengthened}

In modern higher educational schools, the English major generally puts more emphasis on the teaching of textbook knowledge, especially exam knowledge points. However, textbook knowledge and exam knowledge points are mostly theoretical knowledge such as grammar and skills (for listening, reading, writing, translation and speaking), and the practical nature of English language has been neglected. As we all know, linguistics is a professional subject with obvious practical nature; besides the support of theoretical knowledge, it's necessary to integrate theory with practice, and verify the theoretical knowledge through practice and exercises to further promote the development of theories; moreover, the development of theories can also help improve the effect of practice, and expand the application fields and levels of the practice, so that the teaching model of English major can form a virtuous cycle. Therefore, strengthening the integration of theoretical knowledge and practical exercises of English major courses is a key factor for the improvement of the training quality of college English majors.

\subsection{Inadequate training for the innovation ability of students, and their professional vision needs to be expanded}

Judging from the comprehensive ability assessment results of college English majors, most of them can meet the academic requirements of ordinary professional courses and obtain good scores in exams. However, once they encounter new knowledge that is not included in the syllabus or need to solve unfamiliar problems, most students do not know how to solve these problems or have no idea at all, which reflected that although these students have a good theoretical knowledge background, they still lack the practical language application ability and they do not have the abil- 
ity to discover, summarize and solve problems independently, that is, the English majors generally have inadequate innovation ability, which resulted in that they do not have a vision for English discipline, they cannot see the development and application trend of English discipline from a professional perspective, which will have an impact on the improvement of their training quality.

\subsection{Less occupation directions for English majors, and the application fields need to be broadened}

Compared with other engineering majors, the teaching content of language majors has less expertise; but seeing from the perspective of economic globalization, English major has the feature that it can be combined with other disciplines and majors, and thereby forming various interdisciplinary application fields with professional features, and these application fields include not only the traditional industries such as international trade, international tourism, and professional translation, but also some advanced manufacturing industries that require to conduct international cooperation and exchanges such as technical and management exchanges, and scientific research program cooperation, etc. All these require the English major in colleges and universities to pay attention to integrate student training with the potential and possible application fields, so as to broaden the occupation directions of college English majors.

\subsection{Single student training goal, and the teaching concept can hardly catch up with the requirement of the times}

The training goal of English major in modern colleges and universities is single and undiversified, it generally focuses on the teaching of general knowledge and the application of such knowledge; especially in some application-type higher education schools, the English major often pays more attention to the training of English skills of English majors, and less emphasis has been paid to the training of their overall English cultural quality and development potential, and this has resulted in that the single student training goal cannot truly reflect the essential content of the teaching of English major, and it disconnects with the teaching concept of higher education in current society, as a result, the student training goal of English major in colleges and universities lost the touch with the teaching concept of modern higher education, and it cannot meet the actual requirement of social development.

\subsection{Unclear training plans and low intelligent-level of English education}

The 21 st century is an era of knowledge, it has a high requirement on high-level professional talents, so the development level of modern higher education must be in line with the requirements of current society, and this calls for that the training plans of English major in colleges and universities should have clear connotations and essential content. However, since quality-oriented education hasn't been deeply implemented yet and different education administrators, educators, teachers and students have different understandings and recognition levels for modern higher education, when education administrators, educators, and teachers are formulating training plans, 
they neither have a unified standard nor a clear training goal. Meanwhile, for college English major students, their learning purpose usually varies from person to person, which makes the teaching of English courses deviate from the normal track. Moreover, with the fast development of intelligent technologies, there's an increasingly urgent need for introducing intelligent education model into college English teaching, and how to apply these intelligent technologies to English education in colleges and universities has become a key content that needs to be taken into consideration during the training of college English majors.

\subsection{Limited investment in English major and the faculty needs to be further improved}

Relatively speaking, the basic investment in English major in colleges and universities is insufficient. In aspects such as hardware and software infrastructures, highlevel teaching talent introduction, excellent course construction, teacher cultivation, and teaching reform, etc., there are certain gaps between the input in English major and the investment received by science and engineering majors. As we all know, the training quality of college students is closely related to the basic input in college disciplines, insufficient investment would certainly have an impact on the training quality of college English majors. Therefore, increasing basic investment in English major and improve the faculty level of college English major is also an important content that needs to be taken into consideration during the training of college English majors.

\section{Implementation Strategies and Paths for the Training Model of College English Majors}

Through the above analysis of the current situation of the training of English majors in colleges and universities, it can be seen that the implementation of the training model of college English majors is affected by multiple constraint factors. In order to effectively eliminate the influence of these constraints, this paper holds that the following strategies and paths could be adopted, so as to give targeted solutions from multiple angles, thereby improving the training quality of college English majors.

\subsection{Clarify teaching goal and update teaching concept}

Teaching goal is an intuitive manifestation of the training goal of college English majors, as modern education technologies are developing quickly and being applied in higher education extensively, clarifying the teaching goal of English major in colleges and universities is of very important significance. At the same time, as the philosophy of modern education is developing continuously, the teaching concept of English major in colleges and universities needs to develop with the times and should be able to meet the teaching requirements. To clarify the teaching goal and improve the teaching concept of English major in colleges and universities, we need to do a good job in the following two aspects: one is dynamically formulating teaching development goals based on the objective conditions of English major and the student source, the 
other is cultivating the professional quality of teachers in English major and updating their teaching concept in a targeted manner.

\subsection{Build a good English curriculum system and optimize the teaching scheme}

To build a good English curriculum system, we need to start from the following three aspects: first, construct a curriculum framework for the cultivation of English majors in colleges and universities, and form a complete and logical system; second, compile teaching materials within the framework so that they can meet the training requirements; third, construct excellent courses for English major in colleges and universities to further improve the training quality of students. Moreover, to optimize the teaching scheme of English major in colleges and universities, during the construction of the English curriculum system, attention must be paid to work details such as teaching organization and structure, teaching activity and task planning, syllabus formulation, and teaching scheme implementation, etc.

\subsection{Increase social practice link and cultivate students' ability to integrate theory with practice}

Increasing a social practice link in the student training model is an important means to improve the training quality of college English majors, and it is also a key measure for enhancing their ability to integrate theory with practice, for this purpose, works in the following aspects must be done well: first, encourage English major students to actively participate in technical contests of their professional fields, so that they can have a more profound understanding of the professional knowledge they have acquired through the contests; second, create more cooperation opportunities between schools and social institutions, so that English major students can enhance their ability in knowledge transformation through these cooperation programs; third, provide a scientific research and practice platform for English major students, so that they can better exert their personal potentials.

\subsection{Pay attention to the fusion of disciplines and expand the professional vision of English majors}

In modern higher education, various disciplines and majors do not exist independently. With the implementation progress of quality education, the correlations among different disciplines and majors are becoming increasingly tighter and closer. Due to the unique features of language majors, the training of college English majors should pay more attention to this aspect, so as to provide support for the expansion of the professional vision of English majors. This paper holds that, setting professional English courses for different disciplines and majors or introducing knowledge of other disciplines and majors into the courses of English majors is an effective way to build a bridge between English major and other majors. 


\subsection{Use intelligent education technologies to improve the training efficiency} and quality of English majors

Nowadays, intelligent technologies have been widely applied in modern higher education; as an important part of modern higher education, the training of college English majors cannot do without the help of intelligent technologies. This paper holds that, various AI technologies, such as multimedia technology, network technology, information technology, VR technology and computer technology can be used to change the teaching tools of college English education and make the teaching more intelligent; also, by using these advanced education technologies, the teaching method will be more advanced, and the teaching concept will be more scientific, thus, these intelligent technologies can provide important support for improving the training efficiency and quality of English majors.

\subsection{Develop a sound talent training system to point out the direction of high- quality talent training}

A sound training system can provide guarantee, offer guidance, and point out the direction for the cultivation of senior English professionals. This paper holds that, to develop a sound training system for college English majors, various personnel such as the education administrators, the English teachers, English students, and teaching assistants need to be taken into consideration, then combining with the actual conditions in teaching development and management, build a set of rules, regulations, as well as reward and punishment mechanisms for various roles, such as the teacher management system, student management system, assistant management system, and the corresponding teacher performance system, learning performance system, as well as the learning reward and punishment mechanism, etc., so as to mobilize the enthusiasm and initiative of teachers, students and administrators in teaching, learning and managing.

\subsection{Increase investment in student training to provide basic guarantee for the cultivation of high-quality talents}

Investment in student training is the most basic guarantee for the smooth implementation of the teaching activities of English major in colleges and universities, it is also the basic condition for the improvement of the training quality of college English majors. To increase investment in student training, attention needs to be paid to the following three aspects: first, construct software and hardware facilities for student training of English major in colleges and universities, including intelligent classrooms, intelligent English learning platforms, English teaching information centers, and teaching and researching offices, etc.; second, increase input in course teaching of English major in colleges and universities, so as to meet the requirements of various teaching activities; third, provide necessary support for the introduction of senior English teaching talents, so as to build a high-level faculty for English major in colleges and universities. 
3.8 Notice the correlation among pre-class, in-class and post-class training works and establish an information feedback mechanism

A key link in the training of English majors in colleges and universities is the learning process of the students, and problems existing in the learning process of students should be identified and solved in a targeted manner. For this purpose, we need to pay attention to the correlation among pre-class, in-class and post-class training works such as well plan and prepare the teaching content before class, do a good job in classroom teaching, and review the training works after class. With the help of the intelligent learning and communication platform, college teachers in English major can quickly understand the students' learning conditions, then based on their respective situations, the teachers can give solutions in a targeted manner, thereby improving the training quality of college English majors.

\subsection{Expand the learning scope of English majors and the application field of senior English professionals}

Expanding the professional learning scope of English majors in colleges and universities is a good way to improve their comprehensive quality, and it can also act as an effective guarantee for broadening the application fields of senior English professionals and enhancing the employability of English major graduates. To expand the learning scope of English majors, we need to pay attention to works in the following two aspects: first, promote the integration of English major and other disciplines and majors, build channels for the learning of English courses and the courses of other subjects, enhance the connection between English major and other majors; second, do a good job in industry-school-research integration and strengthen the ability to integrate these three in English major, so that the English major students can have better scientific research and innovation ability, which is conducive to improving the training quality of English majors. 


\section{Quality Analysis Model for the Training of College English Majors}

\subsection{Index system for the quality analysis model}

Table 1. Index system for the training quality analysis of college English majors

\begin{tabular}{|c|c|}
\hline First-level index & Second-level index \\
\hline \multirow{8}{*}{$\begin{array}{l}\text { Basic professional } \\
\text { ability }\end{array}$} & English listening ability \\
\hline & English speaking ability \\
\hline & English reading ability \\
\hline & English writing ability \\
\hline & English translation ability \\
\hline & Ability to master professional knowledge in English courses \\
\hline & Concentrate attention on English knowledge learning \\
\hline & Enthusiasm for English knowledge learning \\
\hline \multirow{6}{*}{$\begin{array}{l}\text { Autonomous learning } \\
\text { ability }\end{array}$} & Ability to acquire English knowledge \\
\hline & Ability to manage English knowledge \\
\hline & Ability to memorize English knowledge \\
\hline & Divergent thinking ability \\
\hline & Initiative for English knowledge learning \\
\hline & Persistence for English knowledge learning \\
\hline \multirow{5}{*}{ Innovation ability } & Ability to discover problems during English learning \\
\hline & Ability to analyze problems during English learning \\
\hline & Ability to solve problems during English learning \\
\hline & Thinking ability during English learning \\
\hline & Innovativeness during English learning \\
\hline \multirow{4}{*}{$\begin{array}{l}\text { Coordination and } \\
\text { communication ability }\end{array}$} & Team work ability \\
\hline & Language expression ability \\
\hline & Comprehension ability \\
\hline & \begin{tabular}{|l|} 
Interpersonal skills \\
\end{tabular} \\
\hline \multirow{4}{*}{ Integration ability } & Ability to integrate theory with practice \\
\hline & Ability to integrate English major with other majors \\
\hline & Ability to integrate professional knowledge with social requirements \\
\hline & Ability to transform professional knowledge \\
\hline \multirow{13}{*}{ English learning results } & Overall score of professional English courses \\
\hline & Performance in English level tests \\
\hline & Pass rate of English majors \\
\hline & Excellent rate of English majors \\
\hline & Loss rate of English majors \\
\hline & Unemployment rate of English majors \\
\hline & Ratio of English majors attending graduate schools \\
\hline & Number of times/Ratio of English majors receiving awards in professional contests \\
\hline & Number of times/Ratio of English majors participating in professional contests \\
\hline & Number of times/Ratio of English majors receiving punishments \\
\hline & Social satisfaction \\
\hline & Student employment satisfaction \\
\hline & Supervisor satisfaction \\
\hline
\end{tabular}


Based on the above analysis, this paper holds that the training of college English majors should pay attention to the following aspects: basic professional ability, autonomous learning ability, innovation ability, coordination and communication ability, and integration ability, only in this way, can the training quality of college English majors be improved comprehensively, and modern education can make progress in the direction of quality education. Therefore, when analyzing the training quality of college English majors, the above-mentioned abilities, plus the English learning results should be taken into account, and these aspects are explained as follows.

The basic professional ability of English majors refers to their ability in English listening, speaking, reading, writing and translation, etc. The autonomous learning ability of English majors refers to their ability to learn independently, especially when they are learning new things, it includes their learning initiative, comprehension ability, and English knowledge mastery, etc. The innovation ability of English majors refers to their ability in discovering new knowledge and problems, and analyzing and solving these problems, especially the ability to expand their professional knowledge. The coordination and communication ability of English majors refers to their ability in team work and interpersonal skills. The integration ability of English majors refers to their ability in mastery and flexible use of the professional knowledge they have acquired, especially the ability to merge and transform knowledge of different majors and disciplines. The English learning results refer to their learning achievements, performance, and exam scores, etc., it is the most direct manifestation of the learning effects of English majors. Table 1 summarizes the index system for the training quality analysis of college English majors.

\subsection{Index processing}

It can be seen from the quality analysis index system established above that each index has different types and dimensions, as well as different degree of importance to the analysis system. For this reason, it is necessary to carry out unified scale processing and weight processing on the indices. Assume the initial value of index $\mathrm{j}$ of object i is $V_{i j}(O)=\left[v_{i j}^{L E}(O), v_{i j}^{R I}(O)\right], v_{i j}^{L E}(O) \leq v_{i j}^{R I}(O)$. If index $\mathrm{j}$ is a benefit-type index, the greater the value, the better, then the normalized value of index $\mathrm{j}$ is $G_{i j}(O)$, namely:

$$
G_{i j}(O)=\left[g_{i j}^{L E}(O), g_{i j}^{R I}(O)\right]=\left[\frac{g_{i j}^{L E}(O)}{\max _{1 \leq i \leq m}\left(V_{i j}(O)\right)}, \frac{g_{i j}^{R I}(O)}{\max _{1 \leq i \leq m}\left(V_{i j}(O)\right)}\right]
$$

where, $1 \leq i \leq m, 1 \leq j \leq n, \mathrm{~m}$ represents the number of objects to be analyzed, $\mathrm{n}$ represents the number of indices.

If index $\mathrm{j}$ is a cost-type index, the smaller the value, the better, then the normalized value of index $\mathrm{j}$ is $G_{i j}(O)$, namely: 


$$
G_{i j}(O)=\left[g_{i j}^{L E}(O), g_{i j}^{R I}(O)\right]=\left[\frac{\min _{1 \leq i \leq m}\left(V_{i j}(O)\right)}{g_{i j}^{R I}(O)}, \frac{\min _{1 \leq i \leq m}\left(V_{i j}(O)\right)}{g_{i j}^{L E}(O)}\right]
$$

After the data scale had been unified, entropy weight method [18-21] was adopted to obtain the weights of each index, the specific steps are:

First, according to $G_{i j}(O)$, the normalized value of index $\mathrm{j}$ of object $\mathrm{i}$, a judgment data matrix $\mathrm{G}$ was constructed, that is:

$$
\mathbf{G}=\left[\begin{array}{ccccc}
G_{11}(O) & \cdots & G_{1 j}(O) & \cdots & G_{1 n}(O) \\
\vdots & \vdots & \vdots & \vdots & \vdots \\
G_{i 1}(O) & \vdots & G_{i j}(O) & \vdots & G_{i n}(O) \\
\vdots & \vdots & \vdots & \vdots & \vdots \\
G_{m 1}(O) & \cdots & G_{m j}(O) & \cdots & G_{m n}(O)
\end{array}\right]
$$

Second, the characteristic proportion of object $\mathrm{i}$ with respect to index $\mathrm{j}$ was marked as $P_{i j}(O)$, there is:

$$
\begin{aligned}
& P_{i j}(O)=G_{i j}(O) / \sum_{i=1}^{m} G_{i j}(O) \\
& =\left(g_{i j}^{L E}(O)+g_{i j}^{R I}(O)\right) / \sum_{i=1}^{m}\left(g_{i j}^{L E}(O)+g_{i j}^{R I}(O)\right)
\end{aligned}
$$

Third, $e_{j}$, the information entropy value of index $\mathrm{j}$ was obtained as:

$$
e_{j}=-\frac{1}{\ln m} \sum_{i=1}^{m}\left(P_{i j}(O) * \ln P_{i j}(O)\right)
$$

Fourth, $D_{j}$, the coefficient of difference of index $\mathrm{j}$ was introduced, that is:

$$
D_{j}=1-e_{j}
$$

Then, ${ }^{w_{j}}$, the weight of index $\mathrm{j}$ was obtained to be:

$$
w_{j}=D_{j} / \sum_{j=1}^{n} D_{j}
$$

\subsection{Fuzzy decision analysis process of quality analysis}

Better index values of the object were taken to form a best index dataset $\widetilde{G^{\Delta}}$ as:

$$
\widetilde{G^{\Delta}}=\left\{\max _{1 \leq i \leq m} G_{i j}(O) \mid 1 \leq j \leq n\right\}=\left\{\max _{1 \leq i \leq m}\left[g_{i j}^{L E}(O), g_{i j}^{R I}(O)\right] \mid 1 \leq j \leq n\right\}
$$


Worse index values of the object were taken to form a worst index dataset $\widetilde{G^{\nabla}}$ as:

$$
\widetilde{G^{\nabla}}=\left\{\min _{1 \leq i \leq m} G_{i j}(O) \mid 1 \leq j \leq n\right\}=\left\{\min _{1 \leq i \leq m}\left[g_{i j}^{L E}(O), g_{i j}^{R I}(O)\right] \mid 1 \leq j \leq n\right\}
$$

According to the fuzzy system theory [22-23] and the calculation model of fuzzy distance [24-26], for index $\mathrm{j}$, the fuzzy distance between object $\mathrm{i}$ and the best data set $\widetilde{G^{\Delta}}$ was $d_{i j}\left(\widetilde{G^{\Delta}}\right)$, namely:

$$
d_{i j}\left(\widetilde{G^{\Delta}}\right)=\sqrt[P]{\frac{\left|g_{i j}^{L E}(O)-\max _{1 \leq i \leq m}\left(g_{i j}^{L E}(O)\right)\right|^{P}+\left|g_{i j}^{R I}(O)-\max _{1 \leq i \leq m}\left(g_{i j}^{R I}(O)\right)\right|^{P}}{2}}
$$

where, when $P=1, d_{i j}\left(\widetilde{G^{\Delta}}\right)$ is the Hamming distance; when $\mathrm{P}=2, d_{i j}\left(\widetilde{G^{\Delta}}\right)$ is the Euclidean distance.

For index $\mathrm{j}$, the fuzzy nearness between object $\mathrm{i}$ and the best data set $\widetilde{G^{\Delta}}$ was $\sigma_{i j}\left(\widetilde{G^{\Delta}}\right)$, namely:

$$
\sigma_{i j}\left(\widetilde{G^{\Delta}}\right)=1-d_{i j}\left(\widetilde{G^{\Delta}}\right)
$$

Then, the comprehensive weighted fuzzy nearness $\sigma_{i}\left(\widetilde{G^{\Delta}}\right)$ between object i and the best data set $\widetilde{G^{\Delta}}$ was obtained as:

$$
\sigma_{i}\left(\widetilde{G^{\Delta}}\right)=\sum_{j=1}^{n}\left[w_{j} * \sigma_{i j}\left(\widetilde{G^{\Delta}}\right)\right]
$$

Similarly, for index $\mathrm{j}$, the fuzzy distance between object $\mathrm{i}$ and the worst dataset $\widetilde{G^{\nabla}}$ was $d_{i j}\left(\widetilde{G^{\nabla}}\right)$, that is:

$$
d_{i j}\left(\widetilde{G^{\nabla}}\right)=\sqrt[P]{\frac{\left|g_{i j}^{L E}(O)-\min _{1 \leq i \leq m}\left(g_{i j}^{L E}(O)\right)\right|^{P}+\left|g_{i j}^{R I}(O)-\min _{1 \leq i \leq m}\left(g_{i j}^{R I}(O)\right)\right|^{P}}{2}}
$$

For index $\mathrm{j}$, the fuzzy nearness between object $\mathrm{i}$ and the worst dataset $\widetilde{G^{\nabla}}$ was $\sigma_{i j}\left(\widetilde{G^{\nabla}}\right)$, that is:

$$
\sigma_{i j}\left(\widetilde{G^{\nabla}}\right)=1-d_{i j}\left(\widetilde{G^{\nabla}}\right)
$$

Then, the comprehensive weighted fuzzy nearness $\sigma_{i}\left(\widetilde{G^{\nabla}}\right)$ between object $\mathrm{i}$ and the worst dataset $\widetilde{G^{\nabla}}$ was:

$$
\sigma_{i}\left(\widetilde{G^{\nabla}}\right)=\sum_{j=1}^{n}\left[w_{j} * \sigma_{i j}\left(\widetilde{G^{\nabla}}\right)\right]
$$


According to the physical meaning of fuzzy nearness, larger $\sigma_{i}\left(\widetilde{G^{\Delta}}\right)$ value and smaller $\sigma_{i}\left(\widetilde{G^{\nabla}}\right)$ value indicate that the college English major student training quality of object $\mathrm{i}$ is better, and vice versa. Therefore, a comprehensive optimal fuzzy nearness model was established as follows:

$$
\sigma_{i}=\frac{\left(\sigma_{i}\left(\widetilde{G^{\Delta}}\right)\right)^{2}}{\left(\sigma_{i}\left(\widetilde{G^{\nabla}}\right)\right)^{2}+\left(\sigma_{i}\left(\widetilde{G^{\Delta}}\right)\right)^{2}}
$$

If it satisfies:

$$
\sigma_{k}=\max _{1 \leq i \leq m}\left\{\sigma_{i}\right\}, 1 \leq i, k \leq m
$$

It indicates that the college English major student training quality of object $\mathrm{k}$ is the best.

\section{Conclusion}

This paper studied the training model and quality of college students in English major and analyzed problems existing in the training process. Then on this basis, it proposed several strategies and paths for the implementation of the training model, providing an important support for improving the training quality of college English majors. Besides, in order to correctly evaluate the training quality, this paper also constructed the am index system and a quality analysis model for the said matter.

\section{Acknowledgement}

New Information Technology Innovation Project assisted by Chinese College Industry-University-Research Innovation Fund of Ministry of Education of People's Republic of China, Science and Technology Development Center: A Research on English for Artificial Intelligence Based on the Demand Analysis (2019ITA03023).

\section{$7 \quad$ References}

[1] Dimova, S. (2020). English language requirements for enrolment in EMI programs in higher education: A European case. Journal of English for Academic Purposes, 47: 1-13. https://doi.org/10.1016/j.jeap.2020.100896

[2] Nguyen, H.-T.T. (2020). Communication skills and reflection practice in smart english teaching and learning environment a case study, International Journal of Emerging Technologies in Learning, 15(17): 221-237.

[3] Ding, W. (2020). Influence of road traffic noise on english reading comprehension of Chinese college students majoring in english, International Journal of Emerging Technologies in Learning, 15(14): 109-121. 
[4] Su, N.N. (2018). A Research on the Construction of College English Listening and Speaking Class Based on"POA". Journal of Chengdu Normal University, 34(9): 36-40. https://doi.org/10.3969/j.issn.2095-5642.2018.09.036

[5] Wang, B. (2020). English Teaching Objectives and Measures for Postgraduates from the Perspective of Employment. Journal of Hubei Open Vocational College, 33(18): 181-183. https://doi.org/10.3969/j.issn.2096-711X.2020.18.078

[6] Ma, J.T., Ma, G.H. (2018). A Study of Formative Assessment for Project-based English Teaching. Journal of Southwest Jiaotong University (Social Sciences), 19(6): 105-112. https://doi.org/10.3969/j.issn.1009-4474.2018.06.014

[7] Stoffelsma, L., Spooren, W., Mwinlaaru, I.M., Antwi, V. (2020). The morphologyvocabulary- reading mechanism and its effect on students' academic achievement in an English L2 context. Journal of English for Academic Purposes, 47: 1-15. https://doi. org/10.1016/j.jeap.2020.100887

[8] Soodmand, A.H., Sheilan, S., Reze Malek, M. (2015). On the Relationship among Iranian ESP Learners' Learning Strategy use, Learning Styles and their English LanguageAchievement. Procedia - Social and Behavioral Sciences, 192: 724-729. https:// doi.org/10.1016/j.sbspro.2015.06.079

[9] Gao, L., Yuan, Y.H., Sun, H., Liu, Y. (2020). Practical study on the construction of college English blended teaching mode based on rain classroom:Taking Mudanjiang Medical College as an example. China Medical Education Technology, 34(4): 493-497. https://doi.org/10.13566/j.cnki.cmet.cn61-1317/g4.202004023

[10] Li, Q., Li, J. (2020). The Construction of College English Teaching Model from Crosscultural Perspective. Journal of Educational Institute of Jilin Province, 36(6): 102-105. https://doi.org/10.16083/j.cnki.1671-1580.2020.06.023

[11] Zhou, W. (2020). A Study on the Teaching Mode of College English Based on PBL under the Training Goal of Applied Talents. Journal of Hubei Open Vocational College, 33(13): 175-176. http://dx.doi.org/10.3969/j.issn.2096-711X.2020.13.078

[12] He, B.B. (2017). Research on the problems and Countermeasures of College English Teaching in the new era. Course Education Research, (27): 175-176. https://doi.org/10.39 69/j.issn.2095-3089.2017.27.001

[13] Dvorghets, O.S., Shaturnaya, Y.A. (2015). Developing Students' Media Literacy in the English Language Teaching Context. Procedia - Social and Behavioral Sciences, 200: 192198. https://doi.org/10.1016/j.sbspro.2015.08.051

[14] DeWaelsche, S.A. (2015). Critical thinking, questioning and student engagement in Korean university English courses. Linguistics and Education, 32: 131-147. http://dx.doi. org/10.1016/j.linged.2015.10.003

[15] Davarpanah, A., Mirshekari, B. (2019). A mathematical model to evaluate the polymer flooding performances. Energy Reports, 5: 1651-1657. https://doi.org/10.1016/j.egyr.2019. $\underline{09.061}$

[16] Pragya, P., Tawatchai, T., Sangam, S. (2020). Evaluation of Soil and Water Assessment Tool and Artificial Neural Network models for hydrologic simulation in different climatic regions of Asia. Science of The Total Environment, 701: 1-12. https://doi.org/10.1016/j. scitotenv.2019.134308

[17] Baktheer, A., Chudoba, R. (2019). Classification and evaluation of phenomenological numerical models for concrete fatigue behavior under compression. Construction and Building Materials, 221: 661-677. http://dx.doi.org/10.1016/j.conbuildmat.2019.06.022

[18] Cavallaro, F., Zavadskas, E.K., Streimikiene, D., Mardani, A. (2019). Assessment of concentrated solar power (CSP) technologies based on a modified intuitionistic fuzzy 
topsis and trigonometric entropy weights. Technological Forecasting and Social Change, 140: 258-270. https://doi.org/10.1016/j.techfore.2018.12.009

[19] Chukwumaobi, O., Akinlabi, E.T., Howard. O.N. (2020). Selection of phase change material for improved performance of Trombe wall systems using the entropy weight and TOPSIS methodology. Energy and Buildings, 217: 1-10. https://doi.org/10.1016/j.enbuild. $\underline{2020.109967}$

[20] Delgado, A., Romero, I. (2016). Environmental conflict analysis using an integrated grey clustering and entropy-weight method: A case study of a mining project in Peru. Environmental Modelling \& Software, 77: 108-121. http://dx.doi.org/10.1016/j.envsoft.20 15.12 .011

[21] Tuğal, I., Karc1, A. (2019). Comparisons of Karc1 and Shannon entropies and their effects on centrality of social networks. Physica A: Statistical Mechanics and its Applications, 523: 352-363. https://doi.org/10.1016/j.physa.2019.02.026

[22] Najme, M., Hasani, Z.B.M., Masoud, M. (2019). Hybrid task scheduling strategy for cloud computing by modified particle swarm optimization and fuzzy theory. Computers \& Industrial Engineering, 130: 597-633. https://doi.org/10.1016/j.cie.2019.03.006

[23] Watanabe, T., Yoshikawa, T., Ito, T., Miwa, Y., Saga, S. (2020). An infinite-resolution grid snapping technique based on fuzzy theory. Applied Soft Computing, 89: 1-12. https:// doi.org/10.1016/j.asoc.2020.106112

[24] Montechiesi, L., Cocconcelli, M., Rubini, R. (2016). Artificial immune system via Euclidean Distance Minimization for anomaly detection in bearings. Mechanical Systems and Signal Processing, 76: 380-393. http://dx.doi.org/10.1016/j.ymssp.2015.04.017

[25] Ghosh, A., Barman, S. (2016). Application of Euclidean distance measurement and principal component analysis for gene identification. Gene1, 583: 112-120. http://dx.doi. org/10.1016/j.gene.2016.02.015

[26] Bukovšek, D.K., Laffey, T.J., Šmigoc, H. (2020). Completely positive factorizations associated with Euclidean distance matrices corresponding to an arithmetic progression. Linear Algebra and its Applications, 597: 113-132. https://doi.org/10.1016/j.laa.2020.03.0 22

\section{Author}

Jingwei Tang was born on 16th March, 1978, in Xishuangbanna Dai Autonomous Prefecture, Yunnan Province, China. She received B. A. degree of English in 2000 and M. A. degree of Second Language Acquisition in 2008 from Chongqing University and is now a Ph.D. candidate in ELT at Assumption University. She started her career in 2000 in Yuzhou University (renamed as Chongqing Technology and Business University in 2003). She has authored more than 10 papers, coauthored one book, participated in the compiling of two teaching materials, and hosted one provincial research project and one university research project.

Article submitted 2020-12-12. Resubmitted 2021-01-26. Final acceptance 2021-01-28. Final version published as submitted by the authors. 